\title{
Magnetization Reversal and Switching Field of CoPt/Ru Patterned Films
}

\author{
K. Mitsuzuka, T. Shimatsu, H. Muraoka, N. Kikuchi*, and J. C. Lodder* \\ RIEC, Tohoku University, 2-1-1 Katahira, Aoba-ku, Sendai, 980-8577 Japan \\ *SMI, MESA+, University of Twente, Postbus 217, 7500 AE, Enschede, The Netherlands
}

\begin{abstract}
Dot arrays with diameter $D=80-245 \mathrm{~nm}$ were made from $\mathrm{Co}_{80} \mathrm{Pt}_{20}(20 \mathrm{~nm})$ films with a large perpendicular anisotropy energy. Coercivity increases as $D$ decreases, and reaches $7.6 \mathrm{kOe}$ at $D=80 \mathrm{~nm}$. The switching volume for the dot arrays, estimated from the field sweep-rate dependence of the coercivity, was very small in comparison with the dot volume: about $7 \%$ of the dot volume when $D=140 \mathrm{~nm}$, for instance. However, the angular dependence coercivity of these dots exibits a typical rotational type of magnetization reversal. Moreover, MFM images revealed that all the dots show a single domain state during the magnetization reversal. Comparison of the coercivity and the anisotropy field suggests that the reversal process starts from a nucleation at the center of the dot followed by a propagation process. This possibility was confirmed by numerical calculation. It was estimated that the switching field distribution, $S F D$, of dot arrays was mainly due to the distributions of the c-axis of the hcp-CoPt lattice and the dot diameter. Calculated results indicate that the magneto-static coupling between the dot arrays must be a dominant factor in determining the $S F D$ value when the dots are used for patterned media with a recording density of $\sim 1$ Tbits/inch ${ }^{2}$.
\end{abstract}

Key words: CoPt films, patterned films, dot arrays, magnetization reversal mechanism, uniaxial anisotropy, coercive force, switching field distribution

\section{$\mathrm{CoPt} / \mathrm{Ru}$ パターン膜の磁化反転機構とスイッチング磁界}

\author{
三塚＼cjkstart要・島津武仁・村岡裕明・N. Kikuchi*・J. C. Lodder* \\ 東北大学 電気通信研究所, 仙台市青葉区片平 2-1-1 (广980-8577) \\ *SMI, MESA+, University of Twente, Postbus 217, 7500 AE, Enschede, The Netherlands
}

\section{1. はじめに}

垂直磁気ディスクの高密度化には結晶粒の微細化による 転移ジッタの低減が不可欠であり 1 ), 微細化に伴う磁気工 ネルギーの低下により生じる熱擾乱を抑制するため, 一軸 磁気異方性 $K_{\mathrm{u}}$ の増加が必要となる. しかし, 飽和記録を 維持するためには $K_{\mathrm{u}}$ の増加には限界があり, 現行の方式 で 1 Tbit/inch ${ }^{2}$ を超える密度を実現することは容易ではな い. 一方, 磁性薄膜を記録ビットの大きさに物理的に加工 するパターン媒体では, ビットサイズはドットの大きさで 規定されるため, 高密度化させた場合でも高い熱安定性が 期待されている.

パターン媒体では, 一つのドットがビットに対応するため, ドット内では結晶粒間には強い交換相互作用が望まれる.

また, その磁化機構は, ドットの形状, 大きさ, 磁化のコ ヒーレント長などに強く依存すると考えられ, 従来のハー ドディスクの媒体材料とは全く異なる性質が要求される. さらに, 記録の観点からは, 記録へッドの最大磁界と磁界 勾配に対応した, 媒体の保磁力と保磁力分散の調整が必要 となる．記録し易く熱的に安定なパターン媒体の実現にあ たっては磁化機構の明確化とドット径にあわせた材料設計 が必要となる.

ここで, $\mathrm{Ru}$ シード層上に室温で形成した $\mathrm{CoPt}$ 膜は, 最 大で $1.5 \times 10^{7} \mathrm{erg} / \mathrm{cm}^{3}$ の $K_{\mathrm{u}}$ 值を有し, 且つ, 組成により $K_{\mathrm{u}}$ および飽和磁化 $M_{\mathrm{s}}$ の制御が可能である ${ }^{2)}$. また, 粒間の交 換相互作用も比較的大きいと考えられることから, 我々は,
$\mathrm{CoPt} / \mathrm{Ru}$ 膜を用いたパターン薄膜の基礎検討を行ってきて いる ${ }^{3)}$. その結果, $\mathrm{CoPt} / \mathrm{Ru}$ ドットの磁気エネルギー障壁 は, $\mathrm{Co} / \mathrm{Pt}$ 人工格子ドット ${ }^{4) よ り も ~} 1$ 桁程度大きく, $\mathrm{CoPt}$ ドットが熱安定性に優れていること等を明らかにしてきて いる. 今回は, $\mathrm{CoPt} / \mathrm{Ru}$ 膜を使ったパターン膜の, 保磁力, 磁区構造, 磁気異方性の評価を通してその磁化機構の明確 化を図るとともに, 保磁力分散 (Switching Field Distribution, 以降 $S F D$ と表記)の評価を行った。また, その結果を基に, $\mathrm{CoPt} / \mathrm{Ru}$ ドットをパターン媒体に用いる 場合の課題についても議論を行った.

\section{2. 実験方法}

$\mathrm{CoPt} / \mathrm{Ru}$ 薄膜は, UHV-DC, RF マグネトロンスパッタリ ング装置（ANELVA 社製）を用いて，4inchфの Si 基板上 に成膜した. 成膜は全て非加熱で行った. 記録層の組成は, 20at\%Pt-Co とし, 膜厚は $20 \mathrm{~nm}$ とした. また, シード層 には $\mathrm{Ru}(20 \mathrm{~nm})$ を用い, プレシード材料として $\mathrm{Pt}(10$ $\mathrm{nm}) / \mathrm{Ta}(5 \mathrm{~nm})$ を用いた. パターン化する前の薄膜の構造解 析には XRD およびTEM を使用し, 磁化測定には振動試料 型磁力計を用いた. 磁気異方性はトルク磁力計により評価 した．直径 80, 140, $245 \mathrm{~nm}$ のドットを有するパターン膜 をレーザー干渉法により作製し 3), その磁気特性と構造解 析を行った. パターン後の薄膜の磁化曲線は, 測定感度の 高い異常ホール効果を利用して行った ${ }^{3}$. 


\section{3. ドットの磁化反転機構と保磁力}

\section{1 構造, 保磁力ならびに磁区}

構造解析の結果，作製した $\mathrm{CoPt}$ 膜は膜面に垂直に $\mathrm{c}$ 軸 が配向しており, その角度分散 $\Delta \theta_{50}$ は 2.8 度と優れた結晶 配向性を有していた. Fig.1 には，作製した CoPt 膜の平面 TEM 像（暗視野像）を示す. 平均粒径が約 $15 \mathrm{~nm}$ の緻密 な多結晶薄膜である。一方, 作製した $\mathrm{CoPt}$ 膜の $K_{\mathrm{u}}$ および $M_{\mathrm{s}}$ は，それぞれ， $1.24 \times 10^{7} \mathrm{erg} / \mathrm{cm}^{3}$ および $1180 \mathrm{emu} / \mathrm{cm}^{3}$ であった.この值は, 異方性磁界 $H_{\mathrm{k}}=21.0 \mathrm{kOe}$ に対応する.

この薄膜を用いて, レーザー干渉法により作製したパタ ーン膜の一例として, Fig.2 には, ドット径 $D$ が $140 \mathrm{~nm}$ のサンプルの SEM 像を示す．ドット径によらず，ピッチ

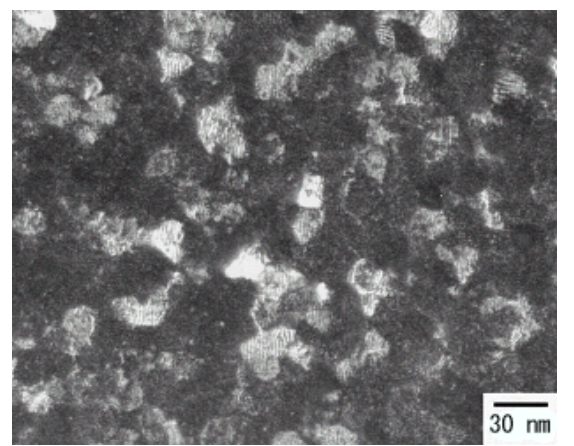

Fig. 1. TEM dark field image of $\mathrm{Cos}_{0} \mathrm{Pt}_{20}$ film.

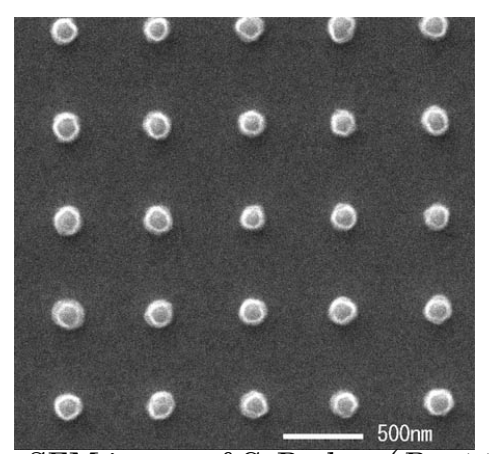

Fig. 2. SEM image of CoPt dots $(D=140 \mathrm{~nm})$.

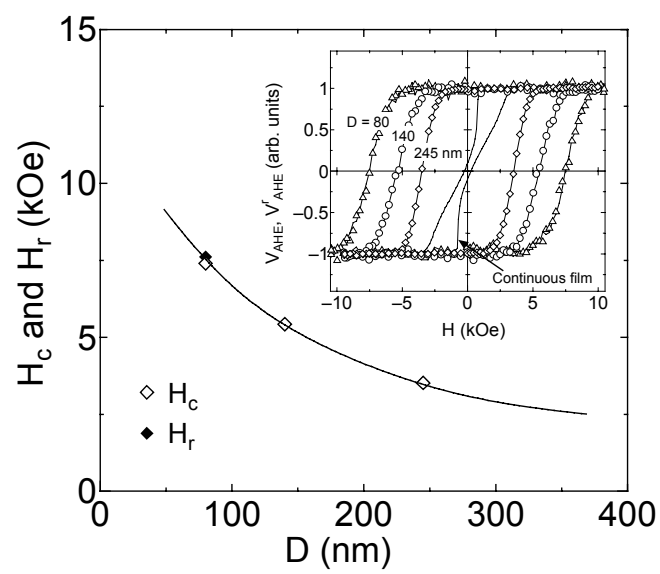

Fig. 3. Values of $H_{\mathrm{c}}$ and $H_{\mathrm{r}}$ as a function of $D$. The magnetization curves of these dot arrays and $\mathrm{CoPt}$ continuous film ${ }^{3)}$ are also shown in the figure.
$600 \mathrm{~nm}$ の周期でミリメータ領域に及ぶ広範囲にドットを 形成した。ドット径に対して厚みが十分薄くピッチが十分 に大きいため，ドット間にはたらく静磁気的な相互作用は ほぼ無視できる.また, ドットの形状は, ほぼ円形である.

Fig. 3 には, 作製した $D=80,140,245 \mathrm{~nm}$ の各ドット膜の 膜面垂直方向の保磁力 $H_{\mathrm{c}}$ および残留保磁力 $H_{\mathrm{r}}$ を， $D$ に対 して示した。図中には, 各ドット膜およびドット加工前の 連続膜の磁化曲線も示してある. これらの磁化曲線は, 多 数のドットにわたる磁化変化を評価した值である ${ }^{3)}$. ドッ 卜膜の磁化曲線と残留磁化曲線は実験誤差の範囲で一致し, $H_{\mathrm{c}}$ と $H_{\mathrm{r}}$ の值は, ほぼ一致した ${ }^{3)}$.このことは, 個々のド ットの磁化の非可逆反転を意味している. ドット径が小さ くなるにつれて $H_{\mathrm{c}}$ が増加し， $D=80 \mathrm{~nm}$ における $H_{\mathrm{c}}$ は 7.6 $\mathrm{kOe}$ に達していた. また, ドット加工の前の連続膜の磁化 曲線に比べ, パターン化により $H_{\mathrm{c}}$ が 1 桁程度増加している ことがわかる。

Fig.4 には，これらのドット膜の $H_{\mathrm{r}}$ の印加磁界角度 対する依存性 3)を示す. $H_{\mathrm{r}}$ の值は，膜面垂直方向の值で規 格化した，図中には，c 軸の角度分散が，今回の $\mathrm{CoPt}$ 膜に 対応する 2.8 度の場合の Stoner-Wohlfarth 型（S-W 型） 磁化反転を仮定した場合の $H_{\mathrm{r}} / H_{\mathrm{k}}$ の值も示した。いずれの ドット径においても， $H_{\mathrm{r}}$ は $\phi=45$ 度付近に極小を示す磁化 回転型の角度依存性を示している。また，その角度依存性 は， $D$ によらず定量的にもほぼ一致し，明確な差が見られ ない. また, $\mathrm{S}-\mathrm{W}$ 型の計算結果とも比較的良く一致してお り，あたかも，ドット全体がコヒーレントな磁化反転を生 じているように見える.

Fig.5 には， $D=245 \mathrm{~nm}$ のドットの MFM 像を示す. 図 中(a)は，十分に大きな磁界を膜面垂直方向に印加してドッ 卜磁化を飽和させた後の像であり，(b)は，さらに $H_{\mathrm{r}}$ と等 しい磁界を逆方向に印加した後の像である． $H_{\mathrm{r}}$ と等しい磁 界を印加することにより，半分の粒子の磁化が反転してい るが，いずれも単磁区を示し，多磁区構造は観察されなか った。 しかし，ドットの大きさは CoPt のコヒーレント長 よりもはるかに大きいため，このように大きなドット径の 磁化全体がコヒーレントに反転しているとは考え難い.

Fig.6 には, ドット径 $140 \mathrm{~nm}$ のサンプルの膜面に平行に 十分に強い磁界（20 kOe）を印加させた後で磁界を取り去 った後の MFM 像を示した. いずれのドットも多磁区構造 を示している。即ち, 準安定状態として多磁区構造は存在 するが，磁化がスイッチングにより反転する際には，多磁 区は形成されないことを意味している.

このように, 直径が数百 $\mathrm{nm}$ に及ぶドットの場合でも, その $H_{\mathrm{r}}$ (あるいは $H_{\mathrm{c}}$ ）の角度依存性が $\mathrm{S}-\mathrm{W}$ 型に近い挙動 を示すことは, Co 系の人工格子膜等の実験において既に報 告されている 5-9). 特に, Co/Pd 膜を用いた実験 8,9)では, ここに示した結果と同様に, 角度依存性が $\mathrm{S}-\mathrm{W}$ 型に近い挙 動を示すドットにおいても単磁区のドットのみ観察され, 多磁区構造は観察されないことが報告されている. 


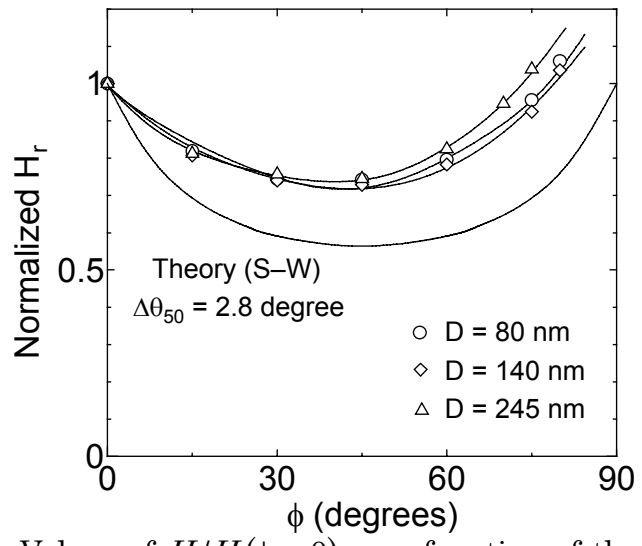

Fig. 4. Values of $H_{\mathrm{r}} / H_{\mathrm{r}}(\phi=0)$ as a function of the angle between the applied field direction and the direction normal to the film plane ${ }^{3)}$.

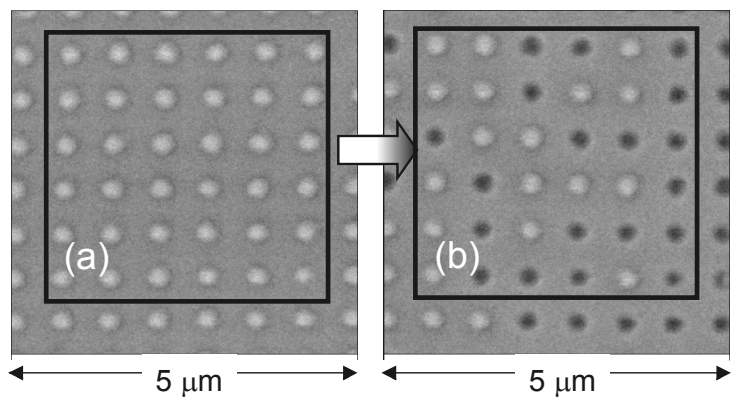

Fig. 5. MFM images of CoPt dot films with $D=245 \mathrm{~nm}$ (a) Saturation remanent, (b) after removal of an applied field equal to $H_{\text {r. }}$.

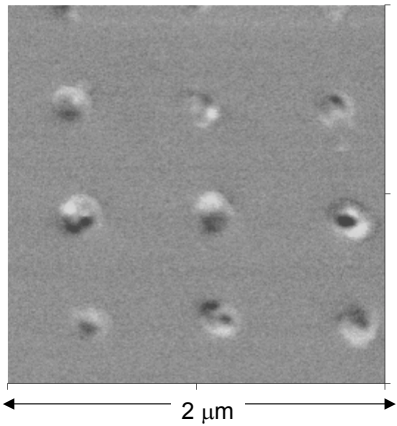

Fig. 6. MFM images of CoPt dot films with $D=140 \mathrm{~nm}$ after removal of an applied field $(20 \mathrm{kOe})$ parallel to the film plane.

\section{2 異方性磁界と磁化反転の単位体積}

このようなドットの磁化機構について明らかにするため, $H_{\mathrm{r}}\left(=H_{\mathrm{c}}\right)$ と異方性磁界との関係について解析を行った.

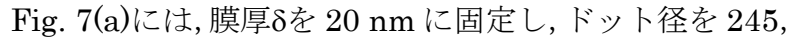
140, $80 \mathrm{~nm}$ と変化させた際の, ドット内部の膜面垂直方向 の反磁界係数 $N_{\mathrm{z}}$ の分布を示した. $N_{\mathrm{z}}$ は, $1 \mathrm{~nm}$ 四方の単位 セルにドットを面内で分割し，表面磁極から受ける各セル の磁界の大きさを，膜厚の $1 / 2$ の位置で積算することで求 めた。図では，ドット中央を横切る垂直面内における $N_{z}$ の変化を，ドット半径に対して示した． $N_{\mathrm{z}}$ はドット中央部 において最も大きく，Dが大きいほど， $N_{\mathrm{z}}$ の絶対值が増加 する．また， $D$ が大きいほど，ドット端部と中央部の差が 大きくなることがわかる.このような $N_{Z}$ で決まるドット内
の反磁界の大きさと，膜の持つ $K_{\mathrm{u}}$ の大きさから， ドット 内部の実効的な異方性磁界 $H_{\mathrm{k}} \mathrm{eff}$ を下記のように求め, Fig.7. (b)に示した.

$$
H_{\mathrm{k}} \mathrm{eff}^{\mathrm{s}}=2 K_{\mathrm{u}} / M_{S}-N_{\mathrm{z}} 4 \pi M_{S}
$$

計算結果を見ると, ドット中央部の $H_{\mathrm{k}} \mathrm{eff}$ はドット端部にお ける值よりも小さく，特に，Dが $100 \mathrm{~nm}$ 以上の場合は半 分程度の大きさとなっている. ドット径の低下にともない, 特にドット中央部の $H_{\mathrm{k}} \mathrm{eff}$ は増加し，ドットの端部との差が 徐々に低下している.

Fig.8 には，ドット中央とドット端部における $H_{\mathrm{k}} \mathrm{eff} の D$ に対する変化をそれぞれ示した。また，Dの小さな領域に ついては， $N_{\mathrm{z}}$ とドット面内の反磁界係数 $\left(1-N_{\mathrm{z}}\right) / 2$ の差か ら求めた形状異方性 $K_{\mathrm{u}}$ shape と， $K_{\mathrm{u}}$ の大きさから，下記の 式にしたがって求めた実効的な異方性磁界, $H_{\mathrm{k}} \mathrm{eff}$ (shape), も示した。

$$
\left.H_{\mathrm{k}} \mathrm{eff}^{\mathrm{e}} \text { hape }\right)=2 K_{\mathrm{u}} / M_{S}-\left(3 N_{\mathrm{z}}-1\right) 4 \pi M_{S}
$$

ドット径が小さくなると，ドット内の全磁化がコヒーレン トにスイッチングするように磁化過程が変化すると考えら れ，そのような領域における磁化機構を議論するための実 効的な異方性磁界としては, $H_{\mathrm{k}} \mathrm{eff}$ (shape)を用いた議論が適 当である。

ここで， $H_{\mathrm{r}}$ の $D$ 依存性はドット中央部の $H_{\mathrm{k}} \mathrm{eff} の D$ 依存 性と定性的に良く一致している. ドット径が小さくなると， $H_{\mathrm{r}}$ とドット中央部の $H_{\mathrm{k}} \mathrm{eff}$ の差は小さくなり , $D=80 \mathrm{~nm}$ に おける $H_{\mathrm{r}}$ は，ドット中央部の $H_{\mathrm{k}} \mathrm{eff}^{\mathrm{ff}}$ 約 $80 \%$ に達している. このことから，ドット中央部の $H_{\mathrm{k}} \mathrm{eff}$ の值が， $H_{\mathrm{r}}$ を決める 主因となっていることが推察される。なお，ドット径が大 きくなるほど， $H_{\mathrm{r}}$ とドット中央部の $H_{\mathrm{k}} \mathrm{eff}$ 差が広がるが， 両者の定量的な関係については磁化機構の節で後述する.
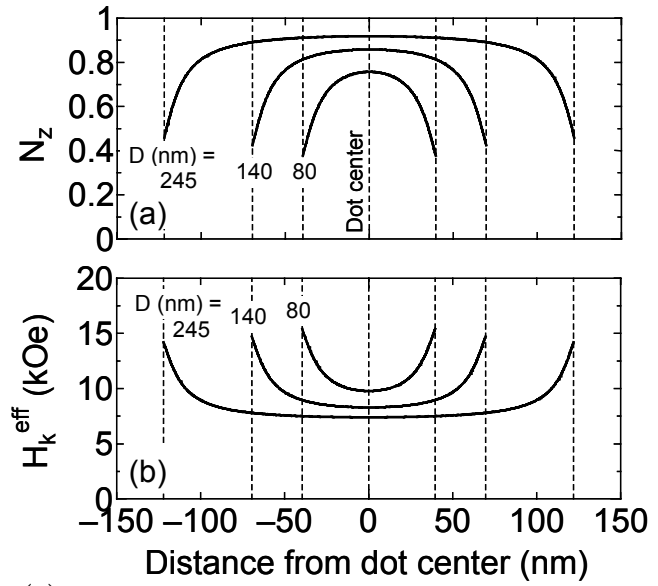

Fig. 7. (a) Demagnetizing coefficients along the direction perpendicular to the film plane, $N_{\mathrm{z}}$, for dots of $D=245$, $140,80 \mathrm{~nm}(20 \mathrm{~nm}$ thickness $)$, respectively, (b) the $H_{\mathrm{k}}$ eff values of these dots. 


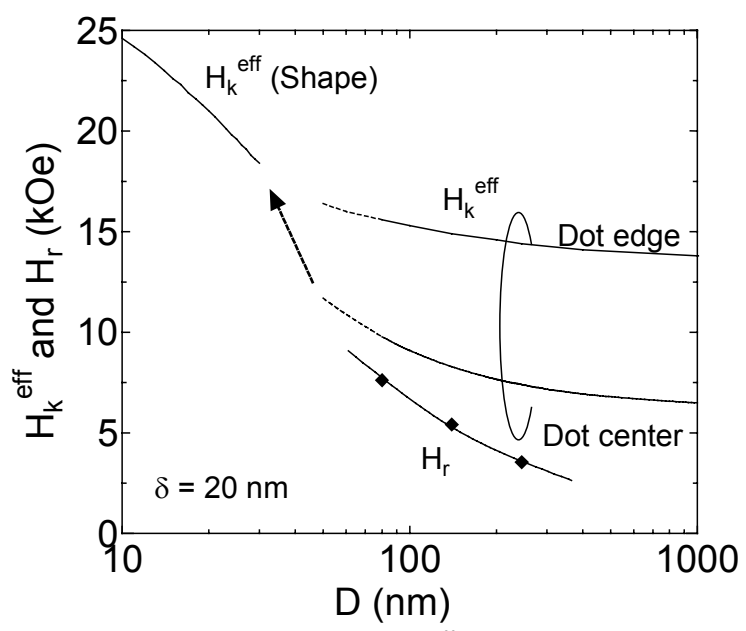

Fig. 8. Calculated values of $H_{\mathrm{k}}$ eff at the dot-center and the dot-edge, respectively, and $H_{\mathrm{k}} \mathrm{eff}^{\text {shape }}$ ) as a function of $D$. The $H_{\mathrm{r}}$ values of $\operatorname{dots}(D=245,140$, and $80 \mathrm{~nm})$ are also shown.

Table 1 Switching volume $V_{\mathrm{sw}}$ and switching diameter (nucleation diameter) $D_{\text {sw }}$ for dots with $\mathrm{D}=140$ and 245 $\mathrm{nm}$, respectively, which were calculated from the values of the energy barrier $E_{0}$ and the effective uniaxial magnetic anisotropy energy $K_{\mathrm{u}}$ eff.

\begin{tabular}{cccccc}
\hline $\begin{array}{c}D \\
(\mathrm{~nm})\end{array}$ & $\begin{array}{c}E_{0} \\
(\mathrm{erg})\end{array}$ & $\begin{array}{c}K_{\mathrm{u}}{ }^{\mathrm{eff}} \\
\left(\mathrm{erg} / \mathrm{cm}^{3}\right)\end{array}$ & $\begin{array}{c}V_{\mathrm{sw}} \\
\left(\mathrm{nm}^{3}\right)\end{array}$ & $\begin{array}{c}V_{s w} / V \\
(\%)\end{array}$ & $\begin{array}{c}D_{\mathrm{sw}} \\
(\mathrm{nm})\end{array}$ \\
\hline 140 & $1.0 \times 10^{-10}$ & $4.9 \times 10^{6}$ & $2.1 \times 10^{4}$ & 6.7 & 36 \\
\hline 245 & $0.81 \times 10^{-10}$ & $4.3 \times 10^{6}$ & $1.9 \times 10^{4}$ & 2.0 & 35 \\
\hline
\end{tabular}

一方，実効的な磁気異方性の大きさと，磁化反転のエネ ルギー障壁 $E_{0}$ の值から，磁化反転の単位体積を見積もった。 Table1 には， $D=140$ ならびに $245 \mathrm{~nm}$ の各ドット膜にお ける反転単位あたりの $E_{0}$ の值 ${ }^{3)}$ と, Fig.8 の結果から求め たドット中央部における実効的な一軸磁気異方性 $K_{\mathrm{u}} \mathrm{eff}$ の 值 $\left(=H_{\mathrm{k}}{ }^{\mathrm{eff}} M_{\mathrm{s}} / 2\right)$ を示した。 $E_{0}$ は, ドット膜の $H_{\mathrm{c}}$ の磁界変 化速度に対する変化から求めた值である 3,10$)$. また，これ らの值から求めたスイッチング体積 $V_{\mathrm{sw}}$ の值 $\left(V_{\mathrm{sw}}=E_{0} / K_{\mathrm{u}} \mathrm{eff}\right.$ と近似）と，ドット体積 $V$ との比の值，ならびに， $V_{\mathrm{sw}}$ を 膜厚 $(20 \mathrm{~nm})$ の円柱に置き換えた際のスイッチング径 (ニ ユークリエーション径) $D_{\mathrm{sw}}$ も示してある． $V_{\mathrm{sw}}$ はドット体 積の 7\%以下の值であり, 磁化反転の基本体積は, ドット の僅か一部の大きさであることを意味している． $D_{\mathrm{sw}}$ の值 は，Dによらず約 $35 \mathrm{~nm}$ 程度となっており，この值は，磁 化のコヒーレント長に関係した值であると考えられる。な お, 解析の結果, 磁化の熱擾乱の影響を差し引いた残留保 磁力 $H_{0}$ の值は， $H_{\mathrm{r}}$ よりも $10 \%$ ほど高い值となることがわ かった。

\section{3 ドットの磁化機構}

以上の結果から，Fig.9 には，予想されるドットの磁化 反転について模式的に示した．印加磁界がある大きさ

$\left(=H_{\mathrm{r}}\right)$ になると, 反磁界の最も大きなドット中央部で磁 化回転によるニュークリエーション（スイッチング）が生
じる (図中(a))。この磁化回転によるニュークリエーショ ン領域の大きさは, 上記の $D_{\mathrm{sw}}$ の大きさである約 $35 \mathrm{~nm}$ の 大きさと予想される. ドット内の磁化は交換相互作用で結 合しているため, ニュークリエーションが生じると，それ による磁化反転は瞬時にドット内の全体に広がり（図中 (b)), 単磁区構造が得られる (同図(c)) と考えられる。今 回実験を行ったドット径の範囲ではドット径に依らずこの ような反転が生じているものと推察される。ここで，ニュ ークリエーションが瞬時に膜全体に広がるためには, 磁化 回転によるニュークリエーション磁界 $H_{\mathrm{n}}\left(=H_{\mathrm{r}}\right)$ に比べて, 磁壁保磁力 $H_{W}$ が十分に小さいことが必要となるが，Fig.3 に示したように，連続膜の $H_{\mathrm{r}}$ はパターン膜の $H_{\mathrm{r}}$ よりも 1 桁以上小さく，この仮定の妥当性を示している. 今回のよ うに，反転核のニュークリエーションと，その伝播という 二つの連続したプロセスを伴う磁化過程の場合, 二つのプ ロセスのうち支配的な磁化回転型の磁化機構が，Fig.4 に 記したドットの $H_{\mathrm{r}}$ の角度依存性に現れていると考えられ る.

この磁化反転モデルの可能性を理論的に検証するため, $D=250 \mathrm{~nm}$ のドットを仮定して磁気エネルギーの計算を行 った．Fig.10には，ドット内に生じたバブル磁区の大きさ $D_{0}$ に対して, 磁気エネルギーの变化を示している. 計算で は, 磁壁厚み $\delta_{\text {wall }}$ を $13 \mathrm{~nm}$ 一定 $\left(\delta_{\text {wall }}=2^{1 / 2} \pi\left(A / K_{\mathrm{u}}\right)^{1 / 2}\right.$, 交 換定数 $A=1.0 \times 10^{-6} \mathrm{erg} / \mathrm{cm}, K_{\mathrm{u}}=1.2 \times 10^{7} \mathrm{erg} / \mathrm{cm}^{3}$ と仮定） と仮定し，静磁エネルギー，磁壁エネルギー，ゼーマンエ

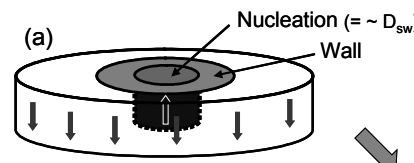

Propagation (domain wall motion)

(c)

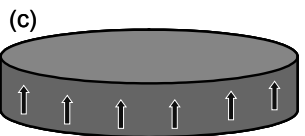

(b) $\quad \mathrm{H}_{\mathrm{w}} \ll \mathrm{H}_{\mathrm{n}}$

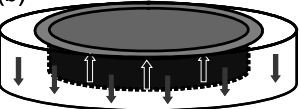

Fig. 9. Magnetization reversal in CoPt dots assumed from experimental results.

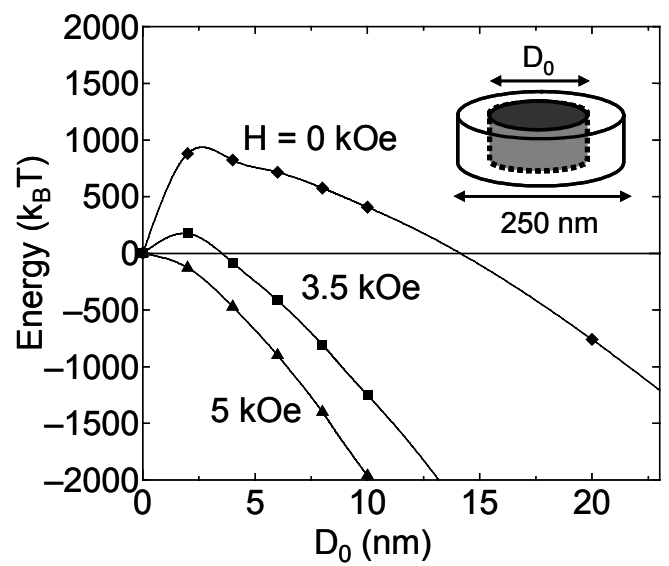

Fig. 10. Calculated values of the total energy of dots as a function of the bubble domain diameter $D_{0}$ for each external field. (assumed $D=250 \mathrm{~nm}$ ). 
ネルギーの総和を算出した．ここで，ニュークリエーショ ンにより形成される磁壁の単位面積辺りの磁壁エネルギー は, 直径に依らず, 磁壁幅と $K_{\mathrm{u}}$ から求めた $15 \mathrm{erg} / \mathrm{cm}^{2}$ $\left(=\delta_{\mathrm{wall}} K_{\mathrm{u}}=2^{1 / 2} \pi\left(A K_{\mathrm{u}}\right)^{1 / 2}\right)$ 一定と近似した。縦軸は $k_{\mathrm{B}} T$ で規格化して示してある（ $k_{\mathrm{B}}$ はボルツマン定数， $T$ は絶対 温度であり，ここでは $300 \mathrm{~K}$ と仮定). 外部磁界が無い場合 には，バブル磁区が無い単磁区状態 $\left(D_{0}=0\right)$ からバブル磁 区を有するような状態へは $850 \mathrm{kB} T$ を超えるエネルギー障 壁が存在し, 単磁区が安定である. しかし外部印加磁界の 増加に伴いエネルギー障壁は低下し，3 5 kOe 程度の磁場 により反転が生じ, 逆向きの単磁区状態まで止まることな く瞬時に反転が進行することがわかった。このことから， 実験的に推察した磁化反転モデルの可能性を裏付けている. なお, R. Dittrich 等は 8,11), 四角いドットの磁化機構につ いてシミュレーションによる解析を行っている. 彼等の結 果でも, ある磁界でドットの一部が磁化回転によるニュー クリエーションを起こし, それが瞬時にドット内全体に広 がる結果が得られており, 我々の結果と定性的に一致して いる，ただし，彼らの計算では，ドットの角がニュークリ エートポイントとなっており，ニュークリエーション位置 が，ドット形状およびドットサイズに依存することを示唆 している.

一方，これらのモデルに基づき，Fig.8 に記した $H_{\mathrm{k}} \mathrm{eff}^{\mathrm{f}}$ と $H_{\mathrm{r}}$ の間の差について考察を加えた. ドット中央部で生じる ニュークリエーションは磁化回転的な挙動を示すため, そ の反転磁界は $\mathrm{c}$ 軸の角度分散の影響を大きく受けることが 予測される. Fig.11には， $D=80 \mathrm{~nm}$ および $245 \mathrm{~nm}$ の 2 種類のドットを例に, スイッチング磁界 $H_{\mathrm{sw}}$ の值を, 膜面 垂直方向と $\mathrm{c}$ 軸のなす角度 $\theta$ 対して示した. $H_{\mathrm{sw}}$ は, ドッ ト中央部の $H_{\mathrm{k}}$ eff $の$ 值をもとに, S-W 型磁化反転を仮定し て計算した結果であり, $\theta=0$ における $H_{\mathrm{sw}}$ が $H_{\mathrm{k}}$ eff に相当す る. $\theta$ の増加にともない $H_{\mathrm{sw}}$ の值は急激に低下していくこ とがわかる.ここで, ドット形成に用いた $\mathrm{CoPt}$ 膜と同じ $\mathrm{c}$ 軸の角度分散 $\left(\Delta \theta_{50}=2.8\right.$ 度 $)$ を仮定した場合, $\theta$ と粒子の 存在確立 $p$ の関係は同図中に示した関係となる.これらの 計算結果を用いて, $H_{\mathrm{sw}}$ の值と $p$ との関係を Fig.12 に示し た. 図中には, $D=80 \mathrm{~nm}$ および $245 \mathrm{~nm}$ のドット中央部の $H_{\mathrm{k}}{ }^{\text {eff }}$ の計算值 (Fig.8), および, $H_{\mathrm{r}}$ の実験值を比較のため 記した.また，横軸を $H_{\mathrm{k}}$ eff で規格化した $p$ の変化について も図中に示してある.

ここで, Fig.7(b)に示したように, 直径 $80 \mathrm{~nm}$ のドット 内の $H_{\mathrm{k}} \mathrm{eff}$ はドット中央から離れることで急激に増加して いる. 磁化回転によるニュークリエーション領域の大きさ

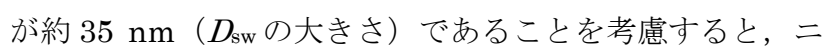
ユークリエーションは, ドットの中央から開始されると考 えられる.ニュークリエーションがドット中央の一つの結 晶粒の $H_{\mathrm{sw}}$ で生じるとすると, $80 \mathrm{~nm}$ ドットの $H_{\mathrm{sw}}$ の期待 值は, Fig.12 において $p$ の最大值を与える $7.6 \mathrm{kOe}$ となる. この值は， $H_{\mathrm{k}} \mathrm{eff} の 0.78$ 倍に低下している.この $H_{\mathrm{sw}}$ は, 実験から得られた $H_{\mathrm{r}}$ と比較的良く一致していることがわ
かる、ただし，実際には $D_{\mathrm{sw}}$ の大きさは結晶粒径よりも 2 倍程度大きく, 隣接した数個の結晶粒の磁化が交換結合し ながらほぼ一斉に回転すると考えられるため, 本来の $H_{\mathrm{sw}}$ の分布は Fig.12 に記した $H_{\mathrm{sw}}$ の分布よりも狭く, また, $H_{\mathrm{sw}}$ の期待值も変化するものと推察され, 定量的な議論に ついては, さらなる検討が必要である.

一方, $D=245 \mathrm{~nm}$ の場合には, $p$ の最大值を与える $H_{\mathrm{sw}}$ の值 $(5.2 \mathrm{kOe})$ は $H_{\mathrm{k}}$ eff 0.71 倍に相当し, $D=80 \mathrm{~nm}$ の 場合よりも, $H_{\mathrm{k}} \mathrm{eff}$ に対する $H_{\mathrm{sw}}$ の低下率が大きい. また, Fig.7(b)に示したように $H_{\mathrm{k}} \mathrm{eff}$ の值がドット中央近傍の広い 範囲で緩慢な極小值を示しているため, ニュークリエーシ ヨンは,この広い範囲内で最も $H_{\mathrm{sw}}$ の小さな結晶粒を二ュ 一クリエーションサイトとして開始することが予測される. したがって, $H_{\mathrm{sw}}$ の期待值は, Fig.12において $p$ の最大值 を与える $H_{\mathrm{sw}} よ り も$ 低磁界側の裾に位置すると考えられ， $H_{\mathrm{r}}$ の実験值 $3.5 \mathrm{kOe}$ と近い值となる.

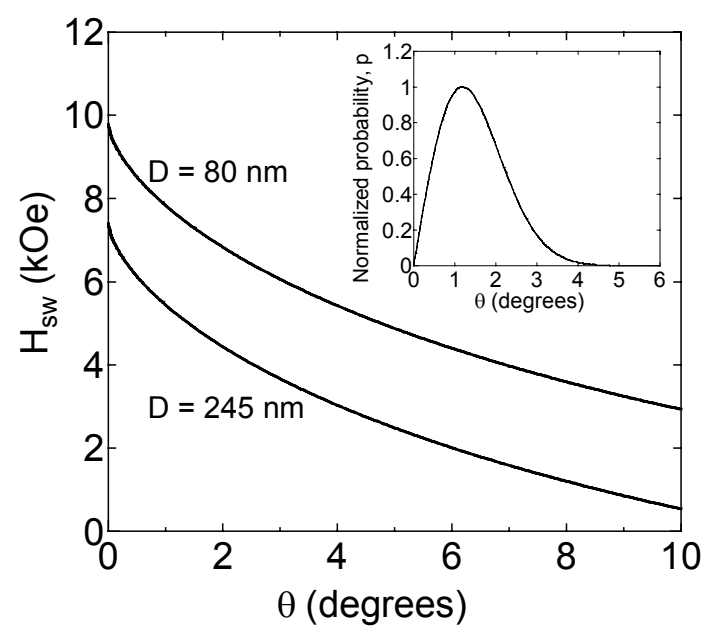

Fig. 11. Values of $H_{\text {sw }}$ calculated as a function of the angle between the c-axis of grains and the direction normal to the film plane, $\theta$. The probability of the number of grains as a function of $\theta$ is also shown as an inset figure.

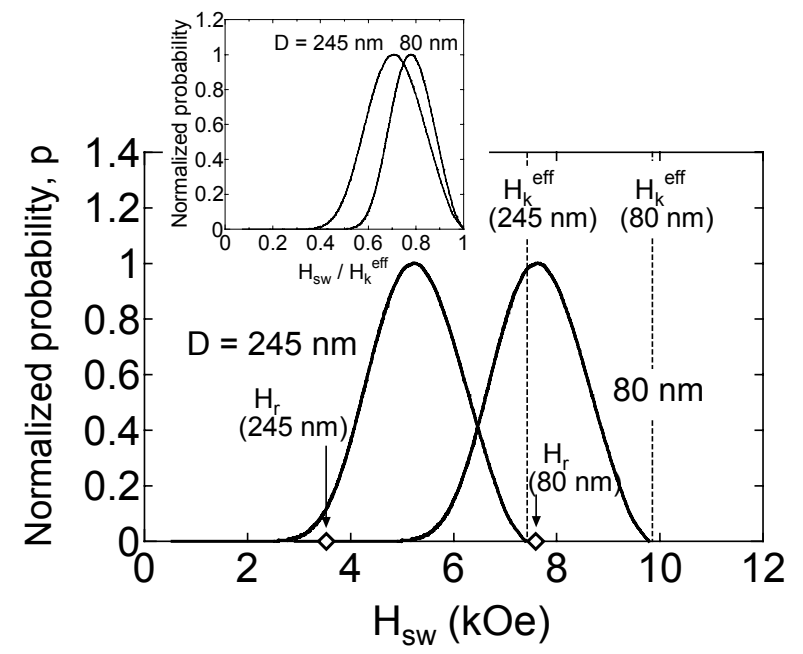

Fig. 12. Probability of $H_{\mathrm{sw}}$ calculated for the dots of $D=$ 80 and $245 \mathrm{~nm}$, respectively. 
これらのことから，c 軸の角度分散と，ドット内の反磁 界の分布，および，二ュークリエーション領域の大きさの 関係を考慮すると， $H_{\mathrm{r}}$ の值（磁化回転による反転核の二ュ ークリエーション磁界に相当）はドット中央の $H_{\mathrm{k}} \mathrm{eff} の$ 值で ほぼ決定されているものと推察される.

これらの結果に基づき, ドット径を $80 \mathrm{~nm}$ よりも低下さ せた際の磁化反転について推察した結果を Fig.13 に示し た. 磁化のコヒーレント長に関係した大きさであると考え られる $D_{\mathrm{sw}}$ は， $D$ を変えてもほとんど変化しない，したが って, $D$ が $D_{\mathrm{sw}}$ (=35 $\mathrm{nm}$ 程度) よりも十分に小さくなる と, ドット内の全磁化がコヒーレントな磁化反転となるこ とが推察される.一方, 1Tbpsi の記録密度は, 単純計算で は $25 \mathrm{~nm} \times 25 \mathrm{~nm}$ のドットピッチに対応し，その際のドッ 卜径は $10 〜 20 \mathrm{~nm}$ になると考えられる。したがって， $\mathrm{CoPt} / \mathrm{Ru}$ ドットで $1 \mathrm{Tbpsi}$ の記録密度に対応するパターン 媒体を作製した場合，ドット内の全磁化がコヒーレントに 反転するようになる臨界的な大きさであると考えられる. なお，ドット径が小さくなると， $H_{\mathrm{r}}$ の值は Fig.8に示した $H_{\mathrm{k}} \mathrm{eff}($ shape)の值にほぼ一致するように, 急激に増加するも のと考えられる. 記録の観点から考えると，このような $H_{r}$ の増大はパターン媒体としては望ましくないが， $H_{r}$ の抑制 に関しては後述する.

\section{4. ドットの保磁力分散}

一方，これらのドットは一つ一つ孤立しているため， Fig.3 に示した磁化曲線の傾きは, ドット毎の $H_{\mathrm{c}}$ の分散 $(S F D)$ に起因する. Fig.14 には, 作製した $D=80,140,245$ $\mathrm{nm}$ の各ドット膜の $S F D$ のドット径依存性を示す.ここで, $S F D$ は, 残留磁化曲線の磁化の值がマイナス $M_{\mathrm{s}} / 2$ からプ ラス $M_{\mathrm{s}} / 2$ に相当する磁界範囲 $\Delta H_{\mathrm{r}}$ を, $H_{\mathrm{r}}$ の值で規格化し て定義しており, 図中には, $\Delta H_{\mathrm{r}}$ および $H_{\mathrm{r}}$ の值も示してあ る. $S F D$ は，Dの低下にともない徐々に低下し， $D=80 \mathrm{~nm}$ では 0.21 となった. $H_{r}$ の值は $D$ の低下にともない増加す るが, その増加率に比べて $\Delta H_{\mathrm{r}}$ の増加率が小さいため, $S F D$ が低下している。

$S F D$ が生じる原因として, まず c 軸の角度分散の影響が 考えられる. ドット径が最も小さな $80 \mathrm{~nm}$ の場合には, Fig.12 に記した $D=80 \mathrm{~nm}$ の $H_{\mathrm{sw}}$ の分布が， c 軸の角度分 散にともなう分布であると近似的に考えることができる.

Fig.12の曲線を $H_{\mathrm{sw}}$ に対して積分して得られる磁化曲線か ら， $\Delta H_{\mathrm{r}}$ と同じ定義で $\Delta H_{\mathrm{sw}}$ を求め， $H_{\mathrm{sw}}$ の期待值（ $p$ が最 大となる $\left.H_{\mathrm{sw}}\right)$ で規格化することで $S F D$ を求めたところ, その值は 0.15. となった。一方，直径が大きな $245 \mathrm{~nm}$ のド ットでは，先に述べたように $H_{\mathrm{sw}}$ の期待值が $p$ の最大值を 与える $H_{\mathrm{sw}}$ よりも低磁界側の裾に位置し, それと共に, 分 布の幅も狭くなると考えられる。このことは，Dの増加に ともない $\Delta H_{\mathrm{r}}$ が低下寸る実験結果と矛盾しない. ただし, $S F D$ のドット径依存性を説明するためには， $H_{\mathrm{r}}$ の変化率 に比べて $\Delta H_{\mathrm{r}}$ の変化率が小さい点について定量的に明らか
にする必要があり，その点については今後の課題である.

$S F D$ に影響を与えるもう一つの原因として, $D$ の分散が ある. Fig.3に示すように, $H_{\mathrm{r}}$ は $D$ に依存するため, $D$ の 分布は $H_{\mathrm{r}}$ 分布を与えることになる。これは, $D$ の分散によ りドット中央部の $H_{\mathrm{k}} \mathrm{eff}$ に分散が生じるためである. 平均ド ット径 $245 \mathrm{~nm}$ のドット膜について，AFM により 200 個 のドットのサイズを測定した結果，平均ドット径 $<D>=245$ $\mathrm{nm}$, 標準偏差 $\sigma=15 \mathrm{~nm}$, 平均值に対する標準偏差の割合 $\sigma /<D>=0.06$ の結果を得た. Fig.3 の $H_{\mathrm{r}} \sim D$ 曲線の傾きか ら，このドット径分散に起因する $S F D$ は $10 \%$ 程度に対応 する.

これらのことから, 今回の $\mathrm{CoPt} / \mathrm{Ru}$ ドット膜の $S F D$ は, $\mathrm{c}$ 軸の角度分散と, ドットサイズ分散の複合的な効果とし て，定量的にも説明可能な大きさであると推察されるが， 詳細は，さらなる検討を要する．なお， $\mathrm{Co} / \mathrm{Pd}$ ドット膜 ${ }^{12}$ ) では,ドット径が小さくなるほじ $S F D$ がきくなっており， 我々の結果とは全く逆であった. 彼らは, その原因として, ドット内に $H_{\mathrm{n}}$ の分散を与えたモデルで説明しているが， それを引き起こす原因については明らかになっていない。 このように，ドットの $S F D$ を決める原因については不明な 点も多く, さらなる検討が必要である.

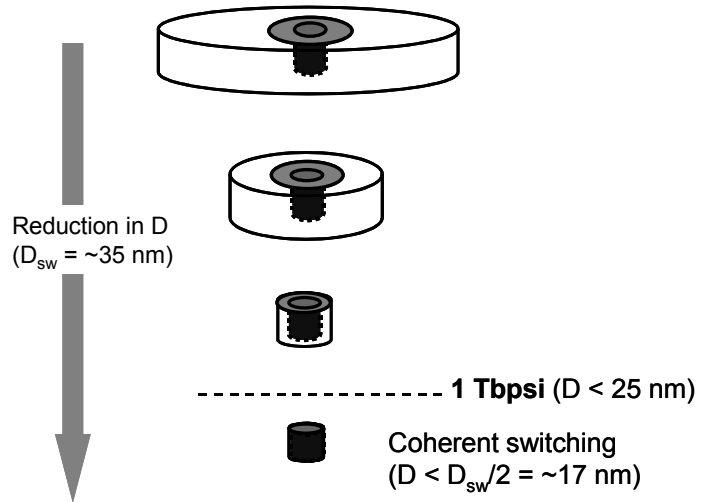

Fig. 13. Schematic model to show the relation between the dot diameter $D$ and the nucleation size $D_{\text {sw. }}$.

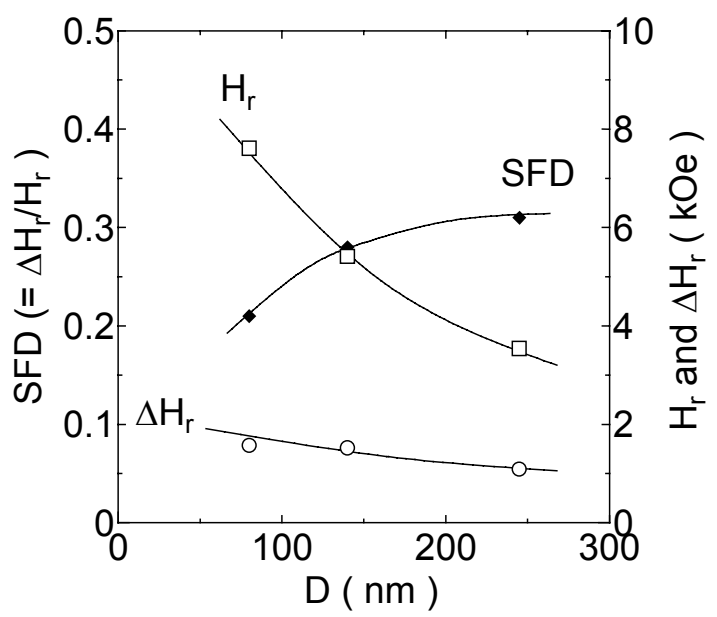

Fig. 14. Values of $S F D, H_{\mathrm{r}}$ and $\Delta H_{\mathrm{r}}$ measured for dots of $D=245,140,80 \mathrm{~nm}$ as a function of the dot diameter, $D$. 


\section{5. ドット間の静磁気的相互作用と磁気特性に関する考察}

一方，今回の実験ではドット間の静磁気的な相互作用は 極めて小さいが，パターン媒体のようにドット密度が高い 場合には, ドット間の静磁気的な相互作用が $S F D$ に及ぼす 影響を考慮する必要がある。ここでは，形状異方性だけで なく, 静磁気的な相互作用を粒子の $H_{\mathrm{k}} \mathrm{eff}$ に取り入れて考 察を行なった.

そこで，1Tbpsi の記録密度に対応する $25 \mathrm{~nm}$ ピッチの ドット配置を仮定して，Dを変化させた場合に，静磁気的 な相互作用が $S F D$ に及ぼす影響を計算した。 Fig.15 に示 すように，計算は， $D \mathrm{x} D \mathrm{~nm}$ の正方ドットが規則正しく配

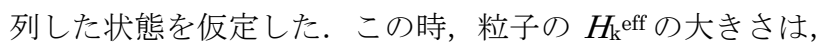
周辺ドットの磁化状態に依存した静磁気的相互作用により 変化すると考えることができる．ドットの磁化反転がコヒ ーレントであると仮定すると, $H_{\mathrm{r}}$ は $H_{\mathrm{k}} \mathrm{eff}$ に一致するため, 磁化状態の違いによる $H_{\mathrm{k}} \mathrm{eff}$ の変化は, $H_{\mathrm{r}}$ の変化に対応す る。計算では，(a)全ドットが一方向に飽和した状態におけ る中央のドットの $H_{\mathrm{k}} \mathrm{eff}$ の大きさと，(b)周囲のドットが全 て反転した後に残った中央のドットの $H_{\mathrm{k}} \mathrm{eff}$ の大きさを計 算した。 それぞれ, $H_{\mathrm{k}} \mathrm{eff}$ の最小值と最大值に対応するため, それぞれを, $H_{\mathrm{k}} \mathrm{eff}(\min )$ および $H_{\mathrm{k}} \mathrm{eff}(\max )$ と定義した.また, 両者の平均值を $H_{\mathrm{k}} \mathrm{eff}(\mathrm{ave})$ とした. $H_{\mathrm{k}} \mathrm{eff}(\mathrm{ave})$ の值は, 磁気 的に孤立したドットの $H_{\mathrm{k}}$ eff と一致している。この值は，ド ット膜の $H_{\mathrm{r}}$ の平均值を示すことになる.

Fig.16には，計算により求めた $H_{\mathrm{k}} \mathrm{eff}(\min ), H_{\mathrm{k}} \mathrm{eff}(\max )$ および $H_{\mathrm{k}} \mathrm{eff}(\mathrm{ave})$ の值を， $D$ に対して示した。ここで，ド ットピッチは $25 \mathrm{~nm}$ 一定であるため, $D$ の低下はドットの 充填率 $f\left(=(D / 25)^{2}\right)$ の低下に対応する。Dが $20 \mathrm{~nm}$ の場

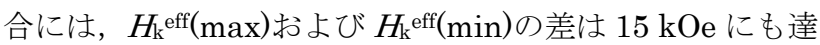
している.Fig.14に示した $S F D$ の定義にならい, $H_{\mathrm{k}} \mathrm{eff}(\max )$

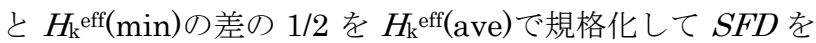
算出すると，その值は 0.38 にも達する。この值は, Fig.14 の值よりも大きな值となる，Dの低下（ドット充填率の低 下）により， $H_{\mathrm{k}}{ }^{\mathrm{eff}}(\max )$ および $H_{\mathrm{k}} \mathrm{eff}^{\mathrm{emin}}$ )の差は小さくなる が，これらの絶対值は増加しており， $D=10 \mathrm{~nm}$ では, $H_{\mathrm{k}} \mathrm{eff}(\max )$ は $25 \mathrm{kOe}$ を超えている.

このように, 1 Tbpsi 相当のドット密度では, ドットの本 質的な $S F D$ とともに，ドット間の静磁気的な相互作用が $S F D$ に大きな影響を与えることになる．SFD を低下する ために $D$ を下げると, 今度は $H_{\mathrm{k}} \mathrm{eff}$ が増加し, ヘッド磁界 で反転させることができなくなる，この $S F D$ および $H_{\mathrm{k}} \mathrm{eff}^{\mathrm{ff}}$ の低下に効果的に作用するのはドット厚である. Fig.17に は，一例として，ドット厚を $5 \mathrm{~nm}$ に低下した際の， $H_{\mathrm{k}}{ }^{\mathrm{eff}}(\max ), H_{\mathrm{k}} \mathrm{eff}(\min )$ および $H_{\mathrm{k}} \mathrm{eff}^{\mathrm{eave}}$ )の值を $D$ 值に対し て記した. 図中には, コヒーレントな磁化反転を仮定した, $K_{\mathrm{u}} \mathrm{eff} V k T$ の計算值も記してある. 膜厚の低下により， $H_{\mathrm{k}} \mathrm{eff}^{\mathrm{f}}$ の絶対值ならびに $H_{\mathrm{k}} \mathrm{eff}$ の最大值と最小值の差が, 大きく低 下している.ただし, $D$ 值を $10 \mathrm{~nm}$ 以下にすると, $K_{\mathrm{u}}^{\mathrm{eff}} V k T$
が 100 以下に急激に低下している。これらのことから，ド ットの膜厚の低下は $H_{\mathrm{k}} \mathrm{eff}$ および $S F D$ を抑制する上で重要 であるが，熱安定性を確保するためには， $D$ 值と膜厚との 最適化を行うことが必要であることがわかる.

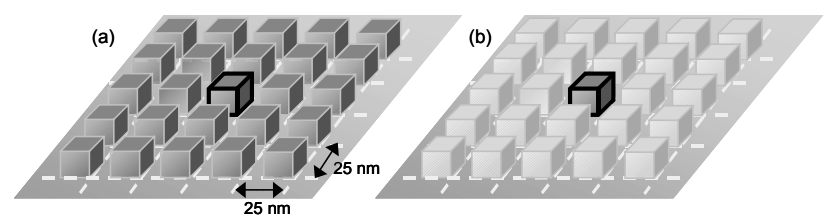

Fig. 15. Calculation models of dot arrays assuming an area density of 1 Tbpsi (dot pitch $=25 \mathrm{~nm})$.

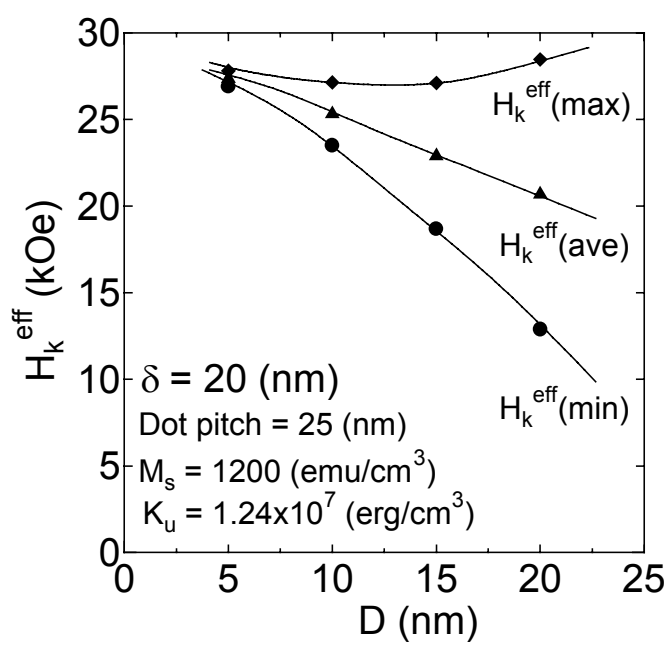

Fig. 16. Calculated values of $H_{\mathrm{k}}$ eff for the dot arrays as a function of $D$. The thickness of the dots is $20 \mathrm{~nm}$.

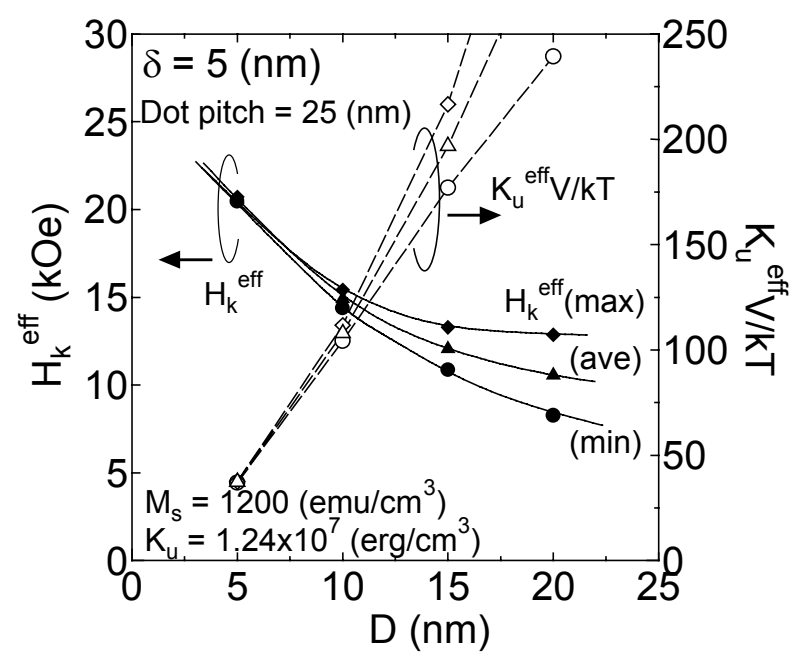

Fig. 17. Calculated values of $H_{\mathrm{k}}$ eff and $K_{\mathrm{u}}$ eff $V / k T$ for dot arrays as a function of $D$. The thickness of the dots is 5 $\mathrm{nm}$.

\section{6. まとめ}

以上，ドット径 80〜245 $\mathrm{nm}$ の $\operatorname{CoPt}(20 \mathrm{~nm}) / \mathrm{Ru}$ ドット 膜の磁気特性について検討した結果，ドット径に依らずス イッチングによる磁化反転を示し， $H_{\mathrm{r}}$ の角度依存性は磁化 回転型を示した。 また，MFM 像の観察でも単磁区が安定 であることが確認された。一方, 磁化反転のエネルギー障 
壁から推定される磁化反転単位は約 $35 \mathrm{~nm}$ となり, ドット 体積よりも 1 桁以上小さな值であった. 磁気異方性の評価 から，このような磁化機構を説明するモデルとして，ドッ ト中央が磁化回転によりニュークリエーションすると瞬時 にドット全体に磁化反転が広がるモデルを提唱し, 数值計 算からも本モデルの可能性を確認した。 また, ドットの $S F D$ は, c 軸の角度分散と, ドットサイズ分散の複合的な 効果として, 定量的にも説明可能な大きさであることを示 した. 一方, これらの結果から, 1Tbpsi の密度に相当する 10〜20 nm のドット径は, ドット全体がコヒーレントな磁 化反転をする臨界的な大きさに対応すると考えられる. 計 算の結果, $1 \mathrm{Tbpsi}$ 相当のドット充填率では, ドットの膜厚 を適切に制御し，ドット間の静磁気的な結合を抑制するこ とが， $H_{\mathrm{r}}$ および $S F D$ の抑制に重要になることを示した.

謝辞 本研究の一部は, 文部科学省平成 16 年度科学技術試験研究 (RR2002, 超小型・大容量ハードディスクの開発）の支援を受け て行われた.ここに深謝する.

\section{References}

1) K. Miura, H. Muraoka, Y. Sugita, and Y. Nakamura, $J$. Magn. Soc. Jpn., 24, 231 (2000).

2) T. Shimatsu, H. Sato, T. Oikawa, Y. Inaba, O. Kitakami, S. Okamoto, H. Aoi, H. Muraoka, and Y. Nakamura, IEEE
Trans. Magn., 40, 2483 (2004).

3) N. Kikuchi, R. Murillo, J. C. Lodder, K. Mitsuzuka, and T. Shimatsu, IEEE Trans. Magn., 41, 3613 (2005).

4) N. Kikuchi, R. Murillo, and J. C. Lodder, "AHE measurement study on Co/Pt nanosized dot", J. Appl. Phys., to be published.

5) N. Bardou, B. Bartenlian, C. Chappert, R. Megy, P. Veillet, J. P. Renard, F. Rousseaux, M. F. Ravet, J. P. Jamet, and P. Meyer, J. Appl. Phys., 79, 5848 (1996).

6) S. P. Li, A. Lebib, Y. Chen, Y. Fu, and M. E. Welland, J. Appl. Phys., 91, 9964 (2002).

7) M. A. M. Haast, J. R. Schuurhuis, L. Abelmann, J. C. Lodder, and Th. J. Popma, IEEE Trans. Magn., 34, 1006 (1998).

8) R. Dittrich, G. Hu, T. Schrefl, T. Thomson, Dieter Guess, B. D. Terris and J. Filder, J. Appl. Phys., 97, 10J705-(1-3) (2005).

9) G. Hu, T. Thomson, C. T. Rettner, S. Raoux, B. D. Terris, J. Appl. Phys., 97, 10J702-(1-3) (2005).

10) R. W. Chantrell, G. N. Coverdale, and K. O'Grady, J. Phys. $D, 21,1469-1471,(1988)$.

11) R. Dittrich, T. Schrefl, Dieter Guess, W. Scholz, and J. Fidler: IEEE Trans. Magn., 40, 2507 (2004).

12) B. D. Terris, M. Albrecht, G. Hu, T. Thomson, and C. T. Rettner, IEEE Trans. Magn., 41, 2822 (2005).

2005 年 10 月 19 日受理, 2006 年 1 月 16 日採録 